\title{
Neo-Globalization: Premises, Processes and the Future
}

\author{
Prof Dr. M S S El Namaki \\ Dean, Victoria University, School of Management, Switzerland. \\ Dean (Retired) Maastricht School of Management, MSM, And The Netherlands.
}

\begin{abstract}
Globalization, or the worldwide movement towards a high measure of economic, financial, trade, technology and communications integration, is a concept in need of an overhaul. The roots which have rested largely on President Reagan's economic policy foundations of the early 80's are wearing off. Free market, deregulation, income and wealth tax cut, reduced government spending and tight fiscal and monetary policies are challenged by events and disruptions. Economic growth vehicles are shifting away from manufacturing and services and locus of economic activity is moving towards China and its environs. Progression towards protective politics in the United States as much as the adoption of Brexit in Britain have hastened the blur.
\end{abstract}

KEYWORDS: Neo-globalization, Premises, processes and the future

\section{The problem}

Globalization, or the worldwide movement towards a high measure of economic, financial, trade, technology and communications integration, is a concept in need of an overhaul. The roots which have rested largely on President Reagan's economic policy foundations of the early 80 's are wearing off. Free market, deregulation, income and wealth tax cut, reduced government spending and tight fiscal and monetary policies are challenged by events and disruptions. Economic growth vehicles are shifting away from manufacturing and services and locus of economic activity is moving towards China and its environs. Progression towards protective politics in the United States as much as the adoption of Brexit in Britain have hastened the blur.

And a new concept of globalization is emerging, neo-globalization.

The following article draws a conceptual and operational framework for this Neo-globalization. It presents a novel framework with new premises and processes. Premises and process that include multi factor inclusion, dynamic cross country synergy, infrastructure investment pivot, conducive capital market frameworks, an economic development component, an international organization drive and last but not least political empathy.

The article provides a novel contribution to the concept of globalization. It highlights opportunities emerging from this new template. It could prove helpful into positioning countries and businesses within the emerging new global economy. It may also be helpful into adjusting mission and modus operandi of institutions as the WTO, The World Bank and the IMF.

\section{What is Neo-globalization?}

Neo-globalization is a process where cross country economic, political, and technological and socio cultural exchange is based on a high measure of rational economic reasoning, institutional innovation, capital market restructuring, disruptive technology accommodation and political empathy. The concept is built on a number of assumptions that include a realization of the limits of the free market, an identification 
of failures of many an international organization, recognition of serious capital market flaws, a recognition of pitfalls in economic development and the dilution of the harsh nature of contemporary politics.

The concept is built on a number of premises within a system process.

\section{The premises}

\section{Cross country dynamic synergy}

Synergy or the creation of a whole that is greater than the simple sum of components and cross country synergy could provide the prime driving force of a globalized economy.

A state of cross country synergy could emanate from present day conditions or tomorrows events and disruptions. Tomorrow's events and disruptions, or Anoff's weak signals (Anoff 1965), rest on the assumption that discontinuities do not emerge without warning and that timely detection of those warnings or "weak signals" is essential for compatible strategic design. Analysis of today's and tomorrow's driving forces of the respective economies creates a framework for synergy-based strategic behavior. The concept is represented in the following diagram where today and tomorrows driving forces of country A and country $\mathrm{B}$ are projected along ay and $\mathrm{x}$ axis of a matrix. Interaction between the two respective country driving forces produces synergies and leads to a synergy based strategic behavior. A strategic behavior that lies at the heart of a globalized economy.

\section{Figure (1)}

\section{The dynamic synergy concept}

\section{Country A future driving forces}

\begin{tabular}{|c|c|c|c|c|}
\hline . & $\begin{array}{l}\text { Driving } \\
\text { force }\end{array}$ & $a$ & $\boldsymbol{B}$ & $c$ \\
\hline & $a$ & \multirow{3}{*}{\multicolumn{3}{|c|}{$\begin{array}{l}\text { Synergy induced } \\
\text { strategies }\end{array}$}} \\
\hline & $\boldsymbol{B}$ & & & \\
\hline $\begin{array}{l}\text { Country B future } \\
\text { driving forces }\end{array}$ & $C$ & & & \\
\hline
\end{tabular}

Synergy congruence could lead to a variety of cross country strategic behavior. The pattern and contents depend on the measure of synergy and the prospective outcome. A high level of synergy could lead to a cross country strategy of industry restructuring, industry concentration, capital market integration, disruptive technology initiatives and enhanced FDI flow (El Namaki, 2016).

\section{Infrastructure investment as a pivot}

Infrastructure investment propels country economic output and drives global economic exchange.

Infrastructure investments in energy, transport, communication, irrigation and water supply raises productivity, reduces costs of market access and increases asset returns. It, more importantly perhaps, influences a country's absolute and comparative advantage by mitigating the constraints of factor 
endowment and promoting intra- and inter-regional integration. Information and communications technology (ICT) infrastructure is, for instance, found to have positive trade effects for both exporters and importers in Asia (ADB, Dec 2015).

Infrastructure investment also stimulates cross country capital flows. Total global infrastructure investment requirements in transport, electricity generation, transmission and distribution, water and telecommunications is expected to reach a USD 71tn by 2030. (OECD ) In addition to being a key enabler of investment, infrastructure can also be a significant and lucrative recipient of investment inflows. Private investment in infrastructure networks, alongside or in place of state-owned operators, has been on the rise worldwide for several decades. Share of infrastructure in total inward FDI volume for individual countries ranged from less than $1 \%$ in Israel to $20 \%$ in Spain and 28\% in Turkey (OECD, 2013).

China's BRI seem to endorse this principal. China's Bridge and Road Initiative is built around an infrastructure investment core with future investment envisaged in cross country roads, high-speed rails, power plants, pipelines, ports, airports and telecommunications links. It is a prudent choice of an effective medium for economic growth and cross country communication. Those investments will not only enhance all forms of exchange but also place China at the heart of a dynamic economic framework embracing.

\section{Restructured capital markets.}

Effective globalized economies require sound global capital market structures and congruent capital market policies.

Disarray in capital markets has undermined, for a time, the globalization process. There was a time, less than a decade ago, when operators declined in number and contracted in scale, products lost their sparkle and shunned by investors, monitors lost credibility andregulatorshave given ideological bias precedence over sound judgment (El Namaki, 2014). Global financial crisis in the year 2008 and beyond prompted renewed reexamination of the architecture of the global financial system especially inadequacies of global governance and systemic risks inherent in financial globalization. Yet, a decade after this global financial crisis, global capital markets and investment banking industry remain constrained. Industry's restructuring efforts introduced sofa seem to have failed to produce the essential outcome. (McKinsey, 2015).

For Neo-globalization to work a restructured capital market is to emerge or one where there is a:

- Well-functioning sovereign debt markets.

- Regulated non-conventional instruments as credit default swaps or CDS's.

- $\quad$ Process and business model for shadow capital markets

- Sound management framework for liquidity pools and liquidity flows.

- Management of Fintech or technology penetration of capital markets products, instruments and institutions.

BRI framework, for instance, allows for the emergence of novel global capital market vehicles and instruments leading to regional financial integration as much as the elimination of barriers to financial integration. And stabilize financial markets after the turbulence of the 2008 crisis. The Asian Infrastructure Investment Bank, a $\$ 100$ billion multilateral development bank dedicated to infrastructure project lending, is one of those. The 40 billion USD business lending development fund, is another.

\section{An economic development component}

Economic development as both a goal and an ideological commitment should become a part and parcel of the Neo globalization concept.

Economic development emerged, historically, as a byproduct of the era of accelerated globalization that preceded the 2008 financial crisis. An era that delivered development enhancing economic growth but also stark and at times perilous imbalances in international trade and capital flows. Post crisis measures do not 
seem to have eliminated those imbalances. Underlying systemic causes seem to persist and can, according to many, only be properly addressed by a global governance reform that allows for an effective incorporation of economic development drivers within the globalization process.

Neo globalization does that. It recognizes economic growth as a strategic goal and a political and ideological commitment. The route to that goes through a reorientation of macroeconomic policies , an infrastructure investment drive, a regulated capital market, an expanded telecommunication network, an endorsement of dynamic technologies and, last but not least, a stimulated entrepreneurial initiative.

China's BRI seem to include many if not most of these features especially the infrastructure investment component. China-Pakistan Economic Corridor (CPEC) is a typical example here. It is a collection of infrastructure modernization projects that cover transportation, energy and special economic zones putting economic life into some of the least developed areas of the country.

\section{Disruptive technology drivers}

Neo globalization accommodates technology disruptions and integrates those within the normal flow of productive events.

Disruption is a radical change in the task or distant environments of an organization or a framework. It is triggered by disruptive forces or breakthroughs that alter current status in a tangible and measurable way. Disruption could be as fast and complete as to destroy existing markets, businesses and technologies and it could be as partial and progressive as to carve out a rapid incremental transformation. Disruptive forces leave a permanent imprint that compels a shift in products, processes and business models to what we may term the "new normal".

Disruption is driven by deep rooted forces (McKinzey, 2014).

First there is the shifting of the locus of economic activity and dynamism to emerging markets and the swelling urban centers within those markets. Those "emerging markets are going through simultaneous industrial and urban revolutions, shifting the center of the world economy east and south at a speed never before witnessed"

Then there is the acceleration in the scope, scale, and economic impact of technology. Technology that is demonstrating ubiquity and instant penetration. Exceptionally fast pace of technological adoption and innovation is leading to shorter life cycles of companies, processes products and, leaders.

And third, there is the accelerating connectivity through information i.e. data and communication as well as capital, people and trade. The outcome is a global economy, and trading system, that is exceptionally intricate and complex with Asia as the emerging hub.

All in all longer term trends are breaking and blurred contours of things to come have only started. The imperative to adjust has never been so compelling.

\section{Regional networks}

Multi country networks focusing on trade, finance and technology cooperation are providing building blocks within the emergingneo-globalization frameworks.

Clusters of countries situated within a specific region who develop favorable regulations for inter network trade, finance and technology exchange are constituting a building block within the neo-globalization structures emerging today.

The Association of South East Asian Nations (ASEAN) has, for example, developed instruments for promoting trade among itsmember's countries through removal of trade barriersand the introduction of freer rules for international flow of capital. ASEAN, who has long had close trading relations with China 
has, more recently, developed close links to the emerging BRI based globalization move. The ChinaASEAN Free Trade Area agreement (ACFTA)concluded in 2010, further improved institutional coordination and introduced intra-regional supply chains boosting the role of ASEAN within the evolvingBelt and Road Initiative.

The Shanghai Cooperation Organization (SCO), is yet another example. It is a Eurasian political, economic, and security grouping created in 2001 that will, most probably, be incorporated into the ongoing BRI rooted globalization drive.

\section{Political empathy!}

Neo-globalization is built on a high measure of political empathy or a degree of mutual understanding and reciprocal appreciation of goals and constraints.

Political empathy assumes an ability to identify with and understand the perspective, experiences and motivations of another party. Also to comprehend and share attitudes, expressions and views of an opposite number. Demonizing those who hold different viewsis substituted by learning how to see them within a positive framework and express empathy despite the different perspective. It is all in strong contrast with the "winner takes it all" culture with its concentration of rewards and waste of investment of past globalization decades (Washington Post, 2014)

It is the author's contention that political empathy is difficult to see in broad daylight. China's BRI seems, however, to provide one of those rare cases where empathy is ingrained in the blueprints of the initiative. Consider President Xi's statement " there's "no point" in blaming economic globalization for the world's problems, many of which have nothing to do with global trade" Also "BRI will serve as a new platform for all countries to achieve win-win cooperation ..." ( January 17, 2017 , NPR) . And the statement by BRI heads of States "We stand for enhancing international cooperation including the Belt and Road Initiative and ... uphold the spirit of peace, cooperation, openness, transparency, inclusiveness, equality, mutual learning, mutual benefit and mutual respect" (Leaders Round Table of Belt and Road Forum, Beijing, 2017).

\section{The emerging model.}

The emerging neo globalization concept can best be represented viewed as a system within a systems theory framework. An input leads to a transformation process that, on its turn, lead to an output. The input is country pertinent resource profile and terms of international exchange. Transformation is built around the variety of drivers of cross country exchange. Outputs, the ultimate product of the process, is value added resulting from cross country economic, technological and cultural exchange.

\section{Figure}

System construct of neo globalization

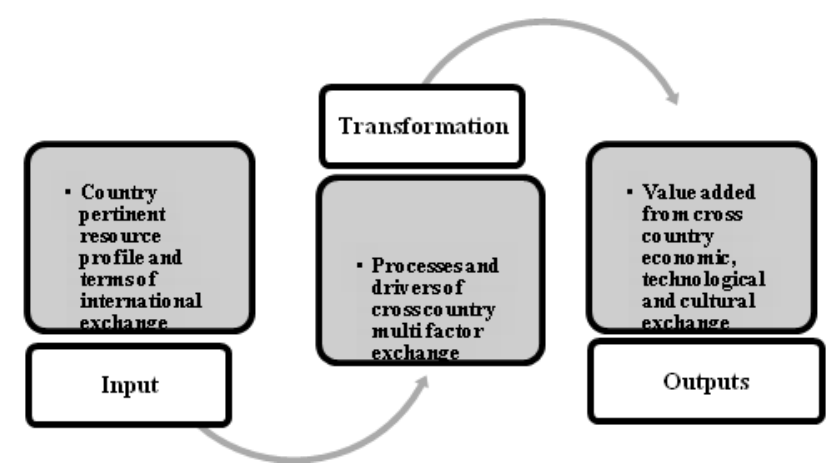




\section{The future}

Neo-globalization processes are more likely to lead to radical shifts in future scenarios. Shifts in country and corporate economic policies and strategies as much as shift in players and driving forces. If one is to project some of those shifts, at considerable cost in accuracy, three specific areas would emerge: capital markets, disruptive technologies and manufacturing industries. The most likely is a shift in overall economic gravity to the East and most probably the ASEAN area led by China. Capital markets will see an operational shift to Far East centers as Shanghai and Hong Kong. IPO bidding have already started the shift. Technology disruption though US dominated today it may go through a shift to yet to be identified locations within the Far East Theater. R and D led product and market development while still strong in the United States and Germany, is likely to be matched by China and, possibly, India. As to manufacturing as a whole the shift will be to the emerging economies of central Asia and central Europe and a bit later to specific Middle East and African locations.

Those are images developing within a blurred screen. Time will provide the focus.

\section{Summary and conclusions}

Globalization, or the worldwide movement towards a high measure of economic, financial, trade, technology and communications integration, is a concept in need of an overhaul. The roots which has rested largely on President Reagan's economic policy foundations of the early 80's are wearing off. Free market, deregulation, income and wealth tax cut, reduced government spending and tight fiscal and monetary policies are challenged by events and disruptions. Economic growth vehicles are shifting away from manufacturing and services and locus of economic activity is moving towards China and its environs. Progression towards protective politics in the United States as much as the adoptionof Brexit in Britain have hastened the blur.

The new concept of globalization emerging from those developments can best be viewed as a system with inputs, transformations and outputs. Premises and process that include multi factor inclusion, dynamic cross country synergy, infrastructure investment pivot, conducive capital market frameworks, an economic development component, an international organization drive and last but not least political empathy.

The future will bring about shifts in several aspects of global operations. Capital markets, disruptive technologies and manufacturing will all undergo a geophysical shift.

\section{References}

[1] Executive Summary from the Inaugural Belt and Road Summit, Hong Kong, 18 May 2016.

[2] Looking at Infrastructure Investments to Boost Economic Growth , January 31, 2017, Efficient Government,

[3] Timo Henckel and Warwick J. McKibbinFriday The Economics of Infrastructure in a Globalized World: Issues, Lessons and Future Challenges, , June 4, 2010

[4] Brooks, Douglas H. (2010). "Asia's Infrastructure and Trade," presentation given at the conference "The Economics of Infrastructure in a Globalised World: Issues, Lessons and Future Challenges," Sydney, 18-19 March, available at http://cama.anu.edu.au/Infrastructure_Conference.asp.

[5] The Economics of Infrastructure in a Globalized World: Issues, Lessons and Future Challenges1 Timo Henckel Centre for Applied Macroeconomic Analysis, Australian National University Warwick McKibbin Research School of Economics, Australian National University The Brookings Institution Lowy Institute for International Policy June 4, 2010

[6] The Impact of Infrastructure on Trade and Economic Growth in Selected Economies in Asia ADB December 2015

[7] Fostering Investment in Infrastructure Lessons learned from OECD Investment Policy Reviews JANUARY 2015September 2016

[8] Daniele Chiarella, Matthieu Lemerle, Ben Margolis, Jared Moon, and Roger Rudisuli , Capital markets and investment banking: Time for real change and bold actions McKinsey, Sept 2016. 
[9] El Namaki, M. S. S.(2016), "From Competitive Advantage to Cross-Country Dynamic Synergy", International Journal of Management and Applied Research, Vol.3, No. 4, pp. 184-191.

[10] STIGLITZ, J “ The world needs a sovereign debt restructuring mechanism”, Global Capital, 12 Oct 2014

[11] Major Belt and Road gains for Asean, The Straits Times, 19 Jun 2017

[12] Understanding ASEAN's Free Trade Agreements, ASEAN Briefing, and February 13, 2014.

[13] Robert F. Bruner, The impact of the winner-take-all phenomenon , Washington Post March 9, 2014

[14] M.S.S. El Namaki, (2014) "How damaged are investment capital markets today?", Competitiveness Review, Vol. 24 Issue: 1, pp.51-58,

[15] Jacob S. Hacker and Paul Pierson. (2010) "Winner-Take-All Politics: Public Policy, Political Organization, and the Precipitous Rise of Top Incomes in the United States* Politics \& Society 38(2) 152-204 SAGE Publication 